\title{
Role of leadership on organizational learning in private universities of Bangladesh
}

\author{
Md. Mahi Uddin \\ PhD Candidate, Universiti Sains Islam Malaysia (USIM) \\ International Islamic University Chittagong (IIUC), Bangladesh \\ Mohammad Aktaruzzaman Khan \\ Department of Business Administration \\ International Islamic University Chittagong (IIUC), Bangladesh \\ Kalsom Ali \\ Faculty of Leadership and Management (FKP) \\ Universiti Sains Islam Malaysia (USIM), Malaysia
}

\begin{abstract}
The study investigates the influence of leadership styles, i.e. transactional and transformational on promoting organizational learning in some selected private universities in Chittagong, Bangladesh. The study used a quantitative research design. Data have been collected from three private universities of Chittagong through a survey instrument. The study analyzed in total 147 matched completed questionnaires. The findings of the study revealed that contingent reward of transactional leadership and idealized influence and individualized consideration of transformational leadership played significant and positive influence on enhancing organizational learning. Although, findings of this research did not report any significant impact of management by exception-active and management by exception-passive as constructs of transactional leadership as well as inspirational motivation and intellectual stimulation as dimensions of transformational leadership style on organizational learning. The study extends present literature in the field by relating leadership styles and organizational learning focusing on emerging economies particularly in the context of Bangladesh.
\end{abstract}

Keywords Transactional leadership, Transformational leadership, Higher education, Organizational learning, Bangladesh

Paper type Research paper

\section{Introduction}

The emergence of private universities is a vital advancement of higher education in Bangladesh. Growing demand for higher education has facilitated the growth of private provision as a way out to minimize pressure on

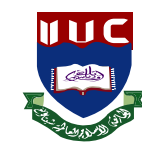

IIUC Studies Vol. 14(2), Dec. 2017 pp. 9-34 (C) IIUC

ISSN 1813-7733 
public universities, and to protect the transfer of tuition fees away from the country, onto students and their families. Private universities have been making significant contributions in the development of higher education system of Bangladesh. Student enrollment in private universities has been increasing day by day because of limited number of public universities and limited scope in public universities. Consequently, the government is allowing to opening private universities at various locations across the country, side by side to open more public universities in several districts. There are now a total of 37 public (funded by the government while managed as self-governed organizations) universities, and 95 private (privately owned and funded by students' tuition fees) universities approved by the government as of June 2016, out of which 90 are operational and 5 are yet to start their operation. Out of 90 operational, 51 are located in Dhaka (the capital city) and 6 are located in Chittagong (the second largest city) and others are located at other districts of Bangladesh (University Grants Commission, 2016:47).

Though there is a remarkable growth in the capability of higher education sector over the last few years, to some extent at the expense of quality. Education in Bangladesh, as a whole, remains well below the standards of various international rankings. The recent survey indicates that no university in Bangladesh either public or private has been ranked out of thousands universities in the world. This indicates that higher education in Bangladesh is not up to the global standard. Though across the QS 2012-13 World University Rankings, just six of the top 500 in the QS rankings are from India and Pakistan (five from India, one from Pakistan) (Shapnochary, 2015).

There is a lack of quality assurance system, quality assurance mechanisms and effective accreditation system across the universities in Bangladesh. In addition, most of the private universities are in ownership problems, irregularities, corruption and doing business in the name of admission in some universities. Because of all these irregularities and allegations against private universities, the government has ordered the closure of a private university and alerted students and guardians about the admission into the university and 48 outer campuses of some private universities have been ordered to stop all sorts of academic activities (UGC, 2017). However, some universities are doing positively to improve quality education without session jam, violence in the campus, with more access to ICT facility, English speaking atmosphere and job facility. Students are able to finish their course within specific time and can go into job market prior to their counterparts studying in public ones. In spite of these positive aspects, the private universities in Bangladesh are 
Leadership and organizational learning 11

not as acceptable as the public universities to the employers and the society. Getting admission into public universities is the prime choice of students in Bangladesh. All these signify the importance of appropriate leadership to lead the private universities in right track and to regain their image, and acceptability to the employers and the society.

A UNDP (2012) report stated that politicization has been highly influencing academic decision making. University top-level management has a tendency to hire and promote individuals having political affiliation rather than academically sound ones. The management also demonstrates very little initiative to promote learning and knowledge of both the academic and administrative staff. Consequently, learning is not facilitated and knowledge creation is not properly inculcated across universities. All of the above-mentioned facts have been contributing to stain the credibility and reputation of private universities in many markets thereby students tend to favor public universities. Hence, many universities are under the threats of survival and growth.

Researchers suggested that if organizational learning (OL) could be nurtured then the survival and growth of universities would be ensured (Nakpodia, 2009; Reece, 2004; Rowley, 1998). Universities across the globe give more emphasis on incorporating learning into the entire process of university (Rowley, 1998). As a result, OL is to be materialized and established across universities (Nakpodia, 2009). However, a good number of previous studies in this vein reported that leadership can play a critical role to make OL happen (Argyris \& Schon, 1996; Davenport \& Prusak, 1998; Edmondson, 1999; Lipshitz, Popper, \& Friedman, 2002; Popper \& Lipshitz, 2000; Schein, 1993; Senge, 1990; Sun \& Anderson, 2011). According to Popper and Lipshitz (2000), leadership is such an aspect that promotes organizational learning by developing an appropriate organizational structure as well as by upholding the organizational values and culture. Similarly, Bryant (2016) argued that leaders can significantly influence to creating, sharing and inculcating knowledge for sustainable competitive advantage. In view of this, researchers suggested two kinds of leadership practices, e.g. transactional leadership and transformational leadership practices that enhance quality of educational institutions at tertiary level (Albulushi \& Hussain, 2008; Avolio, Bass, \& Jung, 1999; Basham, 2010; Bass, 1998; Bass \& Avolio, 1994; Cameron, 1981; Leithwood, 1992; Leithwood, Jantzi, \& Steinbach, 1999; Pounder, 1999; Ramsden, 1998; Senge, 1990; Smart, Kuh, \& Tierney, 1997; Silins, Zarins, \& Mulford, 2002).

In Bangladesh perspective, at all stages of doing research and practical implication, very little effort were undertaken so far to lead and operate 
the higher educational intuitions in ensuring quality. This is mostly due to the Government of Bangladesh makes key decisions to control, to supervise, and to lead the entire tertiary level education system. Government has been doing so with the help of Ministry of Education (MOE) and the University Grants Commission (UGC). The MOE and UGC have the ultimate authority of making decision, executing, and measuring the performance of higher education. Typically, the university education system in Bangladesh is very much centralized in most of the cases like appointing vice-chancellors, pro-vice chancellors, treasurers; appointing academic staff, deciding on the number of students to be enrolled each year, and giving funds to public universities. The Government, in addition, regulates and controls all private universities through UGC applying Private University Act. 2010. Because of such centralized leadership style in higher education in the country, researches who have been doing research on leadership in universities especially in private universities are hardly ever done in Bangladesh (Parvin, 2013). Besides, no empirical research was carried out to investigate the issue of leadership at higher educational institutions in Bangladesh. Considering the prevailing scenario of tertiary education system in Bangladesh, this research is an attempt to answer the following questions:

(1) What is the role of leadership styles (transactional, transformational) to promote $\mathrm{OL}$ at private higher educational institutions in Bangladesh?

(2) Which dimensions of leadership styles are relatively more important for private universities in Bangladesh?

The research begins with studying previous research works on the role of leadership styles (transactional and transformational) facilitating OL with a conclusion of this study. The study explains methodology on which the study is constructed. The study also describes statistical results and findings. Finally, the study elaborated on the discussion and contribution of this present research with a focus on limitations and directions for further research.

\section{Literature Review}

\subsection{Transactional leadership vs. transformational leadership}

In the age of globalization and rapid changes, the researchers agree that leadership is a critical aspect for smooth running of an organization (Denton, 1998; Drucker, 1993; Hallinger, 2011; Senge, 1990). According 
to Robbins, Bergman, Stagg, \& Coultar (2003), leadership is "the process of influencing people on the way to the attainment of goals" and a leader is "someone who can persuade the attitudes and behavior of people and who has the ability to control".

Over the last two decades, a good number of researches have been carried out in the field of leadership, mainly regarding transactionaltransformational leadership. It was first addressed by Burns (1978) and afterward developed by Avolio and Bass (Avolio \& Bass, 2004; Avolio, Bass, \& Jung, 1999; Bass, 1985, 1990, 1998; Bass \& Avolio, 1994). Burns (1978) explained transactional leadership is a system of motivating people by providing rewards for performance, while transformational leadership is the way of motivating and engaging people towards attaining visionary goals and they are likely to give followers' interest over his or her own interest. Transactional leaders practice contingent stimulations of followers and the transformational leaders inspire, intellectually encourage and personally considerate to the followers in accordance with Bass (2010). Bass also stated that transformational leaders integrate the interests of members with the interests of organizations.

Both the styles, transactional and transformational, of leadership are important for guiding an organization towards its success (Ladkin, 2012). Transactional leaders offer distinctive benefits through their capabilities by addressing small operational details rapidly. Transactional leaders manage and deal with all issues and programs creating and sustaining competitive advantage and positioning in the industry, through making individuals dynamic and creative. Transformational leadership has a profound impact on the strategic performance of an enterprise. Transformational leaders can facilitate rapid growth through directing resources towards vision and team-building skills of the leader (Castiglione, 2006). Scholars found a significant impact of transformational leadership in developing organizational learning through information gathering, and bringing changes in the culture and structures of an organization (Zagoršek, Dimovski, \& Škerlavaj, 2009). According to Bryant (2016), transformational leadership could be more useful in generating and distributing knowledge to individuals and groups, whereas, transactional leadership plays key role in making use of knowledge at organizational contexts. Hence, transformational and transactional leadership style of leaders is very effective for managing learning and knowledge in an organization.

The recent studies have pointed out three aspects regarding transactional leadership style and five aspects regarding transformational leadership (Ayoubi, 2015). There are three measures of transactional 
leadership consisting of (i) contingent reward, (ii) management by exception-active, and (iii) management by exception-passive, as suggested by Howell and Avolio (1993). Contingent reward refers to the extent to which the leaders can set specific goals and objectives for employees and can inspire to achieve those giving incentives in turn for accomplishing the targets. Usually, management by exception means the remedial measures taken by the leaders on the basis of outcomes of leader-member interactions. According to Howell and Avolio (1993), management by exception-active and passive mainly differ with regard to interference of leaders. Dynamic leaders study and analyze the activities and manners of followers, predict the difficulties, and take proactive measures before the problems cause unexpected outcomes. Passive leaders are usually reactive and are not likely to take preventive measures rather they wait till the situation to make any difficulties to take corrective measures.

Secondly, there are five aspects of transformational leadership as proposed by Avolio and Bass (Avolio, Bass, \& Jung, 1999; Bass, 1985, 1998; Bass \& Avolio, 1994). They are: (i) idealized attributes, (ii) idealized behaviors, (iii) inspirational motivation, (iv) intellectual inspiration, and (v) individualized consideration. Leaders demonstrating idealized traits and actions (previously the "charisma" dimension) are likely to obtain faith and admiration from employees working with them by warily fulfilling their followers' demands over their own ones, discussing about their key values and thoughts, and focusing on the importance of ethical effects on critical decision making (Avolio et al., 1999; Bass, 1985; Harms \& Crede, 2010). Inspirational motivation refers to the qualities of leaders with the help of which leaders who spell out the importance of achievement and provide challenging tasks to the followers, and persuade them to envisage remarkable support for their job duties and the enterprise. Intellectual inspiration is the set of actions undertaken to motivate members to be innovative, dynamic and inventive by developing inquisitive assumption, redefining problems, and exposing traditional problems in newer ways. Lastly, individualized consideration refers to the action plans highlighting on giving due concentration to employees' personal expectations for accomplishment and development (Bass \& Avolio, 1994; Harms \& Crede, 2010). Though, the three main aspects of transformational leadership; such as: directing resources, making employees dynamic and adaptable and restructuring the organizations that were used by Leithwood and Jantzi (2006) for school effectiveness and improvement. But this research examined the influence of five aspects regarding transformational leadership affecting the learning process of organizations, as suggested by Avolio and Bass at private universities in Bangladesh. 
Leadership and organizational learning 15

\subsection{Organizational learning}

Probably the initial discussion on the issue of OL is related to explaining the notion of learning (Fiol \& Lyles, 1985; Huber, 1991). This concept is related to whether learning takes place when employees gather new knowledge or any relevant change structure and organizational system is required (Easterby-Smith, Crossan, \& Nicolini, 2000; Fiol \& Lyles, 1985). Organizational learning has a direct impact on innovation and positively affects organizational productivity (Aragon-Correa, Varcia-Morales, \& Cordon-Pozo, 2007). Researchers relating to a wholly cognitive standpoint explain learning is an improvement of new outlines throughout the change of concepts and ideas, underlying charts, or understanding diagrams (Kim, 1993). Researchers, supporting a twofold cognitive-behavioral framework, proposed that although cognitive growth is essential, activities are moreover necessary to facilitate inclusive wisdom (Argyris, 1977; Crossan, Lane, \& White, 1999; Garvin, 1993; Spector \& Kim, 2014). Gradually, numerous academic scholars have been using broader notion of organizational learning which include psychological and behavioral facets, possibly regarding the fact that learning could not be distinguished from how an individual perceives the surrounding environment (Easterby-Smith, Crossan, \& Nicolini, 2000).

With a view to examining the improvement of innovative understanding at tertiary educational institutions in Bangladesh and its manifestation on actions, the present research adopts the later aspect of organizational learning. In view of this perspective, organizational learning is a method consisting of four sub systems, such as, acquisition, sharing, and explanation of information and organizational remembrance (Huber, 1991). Collecting information is the system by which organizations identify and collect data and facts to make effective decisions (Huber, 1991; Krogh, Nonaka, \& Rechsteiner, 2012; Slater \& Narver, 1995). Dissemination of data facilitates to encourage useful sharing of information, which is crucial to for learning (Frank \& Ribeiro, 2014; Slater \& Narver, 1995). Interpreting information refers to making information meaningful and identifying how organizations ought to operate with respect to their future strategies (Tippins \& Sohi, 2003). Organizational reminiscence, the last dimension of Huber's approach, indicates accumulated data and organizational objects. Information is accumulated in memory, organization system, design, records, paper and electronic system (Huber, 1991). 


\subsection{Leadership and organizational learning}

In the context of leadership and OL, previous studies revealed that leadership influences significantly to promote OL (Ayoubi, 2015). The majority of prior research works were based conducted on the theoretical issues (Argyris \& Schon, 1996; Davenport \& Prusak, 1998; Edmondson, 1999; Lipshitz, Popper, \& Friedman, 2002; Popper \& Lipshitz, 2000; Schein, 1993; Senge, 1990). The argument of previous works was mostly directed towards linking the impact of leadership in developing context of honesty and psychological wellbeing, which are regarded as the key aspects of OL (Argyris \& Schon, 1996; Edmondson, 1999; Schein, 1993). Previous researchers reported similar findings that are empirically supported in recent times (Ayoubi, 2015).

Leadership styles have been conventionally found to be an important influencing factor for organizational learning (Aragon-Correa, VarciaMorales, \& Cordon-Pozo, 2007). All transformational leadership approaches focus on emotion and ideals (Yukl, 1999) and communicate basically the purpose of developing capability and increased levels of individual commitment to accomplish organizational targets. Increased capabilities and dedications are found to increase performance (Leithwood, Jantzi, \& Steinbach, 1999). The findings of numerous studies reported a significant positive effect of both the transactional and transformational leadership on OL. On the other hand, a good number of studies also reported a direct and positive influence of transformational leadership on OL (Amitay, Popper, \& Lipshitz, 2005; Brown \& Posner, 2001; Chang \& Lee, 2007; Coad \& Berry, 1998; Jansen, Vera, \& Crossan, 2009; Kurland, Peretz, \& Hertz-Lazarowitz, 2010; Lam, 2004; Lam \& Pang, 2003; Nafei, Khanfar, \& Kaifi, 2012; Saekoo \& Yasamorn, 2013; Theodore, 2013). According to Patnaik, Beriha, Mahapatra, \& Singh (2013), fostering and employing transformational leadership to facilitate learning in tertiary educational institutes, i.e. universities, is crucial for developing continuing dedication and loyalty of employees towards organizational learning. Castiglione (2006) reported that library administrators used transformational leadership to foster organizational learning with an attempt to coping to rapid environmental change. Hence, the study posits the following hypothesis:

In terms of transactional leadership, several researchers explored significant positive impact of transactional leadership on sustaining OL (Coad \& Berry, 1998; Jansen, Vera, \& Crossan, 2009; Nafei, Khanfar, \& Kaifi, 2012; Oluremi, 2008; Vera \& Crossan, 2004). Similarly, Jansen et al. (2009) reported transactional leadership activities played a significant role in developing and enriching existing level of knowledge. However, 
insignificant impact of transactional leadership on OL also reported (Amitay, Popper, \& Lipshitz, 2005). The established literature indicates that even though the impact of leadership behavior has not been widely studied by previous scholars (Schein, 1993; Senge, 1990), it still remains at conceptual level. A little research has been empirically tested, though, reveal inconsistency in their findings.

Most of the researches have been conducted so far on private universities in Bangladesh are related to quality perspective. For example, Andaleeb (2003) investigated critical issues to boost enhance quality education in Bangladesh. Sabur (2004) contrasted quality education system of private and public educational institutions in Bangladesh. Besides, Lamanga (2002) conducted a study on measuring quality of education services of private universities in Bangladesh. Later, Lamanga (2006) researched on quality assurance on higher education institutions. All the research works mentioned above recommended that to develop much needed human capital of the country, the private universities should focus on ensuring quality education. In view of this finding, it can be assumed that if the learning could be facilitated then quality assurance objective would be achieved. In a very recent study, Morshed (2016) surveyed on the leadership roles of school teachers in integrating modern technology in class room teaching.

Rapid increase in private universities requires mounting attention in the process of learning to fulfill the educational demands of students. Moreover, private universities have been increasing gradually in number since public (state-funded) universities in Bangladesh cannot fulfill the increasing demands for tertiary education. Though, it is evident from a report on Higher education in South-Asia by The Economist that the most private universities are dependent on public universities' faculty members for teaching (The Economist Intelligence Unit Limited, 2013).

Besides, there is a shortage of studies in this area in the context of emerging economies like Bangladesh. Moreover, the influence of leadership styles on organizational learning has hardly been examined in higher educational institutions like universities (Nakpodia, 2009; Patnaik, Beriha, Mahapatra, \& Singh, 2013) in developing country context like Bangladesh. Hence, this study is an effort to address this important research gap among the existing studies through examining the role of two important leadership styles i.e. transactional and transformational in increasing organizational learning at tertiary level educational institutions in Bangladesh.

\section{Methodology}

Several methods were utilized to explore the influence of leadership behavior on the learning process of universities such as case study method 
(Teixeira, Jabbour, \& Jabbour, 2012), quantitative, qualitative approaches, as well as mixed methods (Jabbour, Jabbour, Teixeira, \& Freitas, 2012; Paille', 2011; Wagner, 2013). However, this study employs quantitative approach based on survey research methodology as it is one of the best measurements in applied social research (Trochim, 2006). Moreover, quantitative study holds the capacity to examine the influence of independent variable(s) on dependent variable(s). In this study, leadership (transactional and transformational) styles and organizational learning are independent and dependent variable respectively. Survey involves asking questions to people (or respondents) with the objectives to know what their opinions are.

\subsection{Sample and procedure}

Data were collected through a questionnaire survey on administrative staff of the three largest, in terms of number of students enrolled, private universities located in Chittagong, the commercial capital of Bangladesh. The researchers recruited a team of 4 members and training was given to the team members about conducting interviews on site because this approach is suitable to produce appropriate data for empirical studies (Zhou, Li, Zhou, \& Su, 2008). Respondents were briefed about the purpose of conducting survey and given assurance of the confidentiality of data provided by them. A total of 187 hard copies of questionnaires were distributed among randomly selected respondents during September and October 2016 of three private universities in Chittagong. The sample universities were selected purposively using judgmental sampling technique. For respondents, simple random was utilized as it has the least bias and offers the most generalized results. In simple random sampling, each participant has an equal likelihood of being included in the sample of a study and purposive sampling refers to the selection of elements that are most advantageously located or in the best point to make the data available needed (Sekaran, 2006:285). Though, sometimes the random sampling can be difficult to handle and expensive when the updated listing of the population is available and judgmental sampling may reduce the generalizability of the findings and requires special efforts to identify and gain access to the sample units to collect requisite data (Moore \& Notz, 2009; Sekaran, 2006). The researchers in this regard have collected the updated list of population prior to conducting the survey. Hence, the researchers face no difficulties in terms of handling respondents only to some extent due to confidentiality of data collected. Finally, the data were collected from three private universities out of six located in Chittagong. These three private universities have been selected purposively because 
these are the largest in terms of number of students and the oldest universities in Chittagong.

Out of 187 distributed questionnaires, 165 completed copies were received from the respondents of selected universities. After reducing incomplete and/or mismatched ones, the final sample of the present research comprised of 147 matched questionnaires with a response rate of $78.6 \%$.

\subsection{Measures}

The study developed survey instrument by adopting scale items from established literature and adapting them to serve the research questions of this research. The study measured all the items employing a 5-point Likert scale. Although, the instrument was basically adopted in English, subsequently it was converted into Bengali, the main language of the people of Bangladesh, and then examined by four university academics to confirm whether the item statements were understandable and clear. The authors used the technique of back-translation method to ascertain the linguistic equality of the two versions. Numerous modifications were brought in the wording of items to prepare the final questionnaire. The process was done in accordance with the comments of academic experts on the content, simplicity, and clearness of measures. To test the reliability, the scale was pre-tested (Creswell, 2012) on 25 administrative staff at sample private universities in Chittagong of Bangladesh.

\section{Leadership styles}

In order to identify leadership styles and to study the impact of leadership (transformational and transactional) styles on OL, the study used the 32item Multifactor Leadership Survey Instrument adopted from Avolio and Bass (2004). This instrument was also applied by Ayoubi (2015) to study the influence of leadership styles on OL at some Syrian select private and public universities. Out of 32 items, transactional leadership includes 12 items and the remaining 20 items are related to transformational leadership dimension. There are three constructs of transactional leadership, which are: (i) contingent reward, (ii) management by exception (active) and (iii) management by exception (passive) consisting of four items for each. An example of item for contingent reward is: "My leader provides me assistance in exchange for my effort"; management by exceptionactive is: "My leader focuses attention on irregularities, mistakes, exceptions, and deviations from standards"; and for transactional leadership-management by exception-passive is: "My leader fails to interfere until problems become serious". In the study of Ayoubi (2015), three items from transactional leadership 
and two items from transformational leadership were dropped as the items got factor loading of less than 0.30 .

Transformational leadership consists of four dimensions such as, transactional leadership - idealized influence, inspirational motivation, intellectual stimulation, and individualized consideration (Avolio \& Bass, 2004). Sample item for idealized influence is: "My leader instills pride in me for being associated with him/ her"; for inspirational motivation is: "My leader talks optimistically about what is needed to be accomplished"; for intellectual stimulation is: "My leader re-examines critical assumptions to question whether they are appropriate"; and for individualized consideration is: "My leader spends time teaching and coaching". Sample participants were invited to evaluate the role of their leaders with regards to the frequency of learning happened. The response scale ranges from 1 for "not at all", to 5 for "frequently".

\section{Organizational learning}

This study considered "organizational learning" as the dependent variable. In order to measure the dependent variable, the study used a 13-item measure constructed by Lopez, Peon, \& Ordas (2004). An example of item is: "The employees attend training courses, fairs, conferences, and seminars regularly". The scale of the extent of learning happened varies from 1 for "not at all", to 5 for "frequently". The Cronbach's reliability coefficient for the items of organizational learning is 0.79 .

\section{Data analysis and results}

In order to analyze, data input were coded and then entered into SPSS 22.0. Blank cases were excluded from the analysis. This section starts with describing demographics of the sample. Then the study carried out factor analysis followed by multiple regressions to study the impact of leadership on learning.

\subsection{Sample demographics}

The study collected 147 questionnaires, as presented in Table 1, from sample respondents. Table 1 shows the demographic data of the sample of this study. Male consist of $87.3 \%$ of the survey respondents followed by $16.3 \%$ female respondents. In terms of educational qualifications, $63.3 \%$ respondents were qualified with graduation followed by bachelor $(23.1 \%)$ and higher secondary $(11.6 \%)$ degree. Respondents with secondary and below comprised of $2 \%$ only. $53.1 \%$ respondents comprised of experience between 6 and 10 years followed by 5 years and less $(29.2 \%)$, and 11 to 15 years $(14.3 \%)$. With regards to levels of management, $12.2 \%$ respondents were from the top level management 
Leadership and organizational learning 21

and the rest of the respondents were from mid-level management $(46.3 \%)$ and lower-level management (41.5\%). About leadership experience, most of the employees $(70.8 \%)$ mentioned that they did not have any leadership experience.

Table 1: Demographics of sample

\begin{tabular}{|c|c|c|c|}
\hline Measures & Particulars & Frequency & Percentage \\
\hline \multirow[t]{3}{*}{ Gender } & Male & 123 & 83.7 \\
\hline & Female & 24 & 16.3 \\
\hline & Total & 147 & 100 \\
\hline \multirow[t]{5}{*}{ Age } & 30 and less & 33 & 22.5 \\
\hline & $31-40$ & 42 & 28.6 \\
\hline & $41-50$ & 63 & 42.8 \\
\hline & 51 and above & 09 & 6.1 \\
\hline & Total & 147 & 100 \\
\hline Educational & Secondary and less & 3 & 2.0 \\
\hline \multirow[t]{4}{*}{ Qualifications } & Higher secondary & 17 & 11.6 \\
\hline & Bachelor & 34 & 23.1 \\
\hline & Post Graduate & 93 & 63.3 \\
\hline & Total & 147 & 100 \\
\hline \multirow[t]{6}{*}{ Length of Service } & 5 years and less & 43 & 29.2 \\
\hline & $6-10$ & 78 & 53.1 \\
\hline & $11-15$ & 21 & 14.3 \\
\hline & $16-20$ & 5 & 3.4 \\
\hline & 21 and above & 0 & 0 \\
\hline & Total & 147 & 100 \\
\hline \multirow[t]{4}{*}{ Managerial Level } & Low & 61 & 41.5 \\
\hline & Middle & 68 & 46.3 \\
\hline & High & 18 & 12.2 \\
\hline & Total & 147 & 100 \\
\hline \multirow[t]{3}{*}{ Leadership Experience } & Yes & 43 & 29.2 \\
\hline & No & 104 & 70.8 \\
\hline & Total & 147 & 100 \\
\hline
\end{tabular}

\subsection{Factor analysis}

The study applied Exploratory Factor Analysis (EFA) to test the validity and strength of the instrument (Sekaran \& Bougie, 2010: 263) of variables and to test the basic structure (Hair, Black, Babin, Anderson, \& Tatham, 2010) of the study. At first, we calculated KMO, as shown in Table 2, value that measures sampling adequacy which is 0.734 , indicating adequate relationships with significant score of the Bartlett's Test of Sphericity (Chi-square $=3312.231, \quad \mathrm{P}<0.05)$. Principal component analysis was applied. Varimax, an oblique rotation was used since it was logical to presume that any extracted factor regarding organizational learning need 


\section{IIUC Studies, 14(2)}

to be inter-correlated. The study applied three usually functional decision rules to find out the number of factors underlying the construct of organizational learning (Hair et al., 2010). Items with factor loading of less than 0.35 and that cross-loadings with other factor(s) at 0.35 or greater were eliminated. An Eigen value of 1 was considered as the threshold value for extraction.

Table 2: KMO and Bartlett's Test

\begin{tabular}{llr}
\hline Kaiser-Meyer-Olkin Measure of Sampling Adequacy & .734 \\
Bartlett's Test of Sphericity & Approx. Chi-Square & $3312.231^{* * *}$ \\
& df & 153 \\
& Sig. & .000 \\
\hline
\end{tabular}

$* * * \mathrm{P}<0.05$

Table 3: Confirmatory factor analysis for environmental performance items

\begin{tabular}{|c|c|c|c|}
\hline \multirow{2}{*}{ Item Description } & \multirow{2}{*}{$\begin{array}{c}\text { Reliability } \\
\text { ( } \alpha \text { value })\end{array}$} & \multicolumn{2}{|c|}{ CFA analysis } \\
\hline & & Eig. val. & Loading \\
\hline Transactional Leadership-Contingent reward & 0.84 & 2.314 & \\
\hline My leader assists me in exchange for my effort & & & 0.781 \\
\hline $\begin{array}{l}\text { My leader discusses specifically on who is responsible for } \\
\text { achieving performance targets (excluded) }\end{array}$ & & & 0.282 \\
\hline $\begin{array}{l}\text { My leader makes it clear on what I can expect to receive } \\
\text { when performance goals are achieved }\end{array}$ & & & 0.804 \\
\hline $\begin{array}{l}\text { My leader expresses satisfaction after I have fulfilled } \\
\text { his/her expectations }\end{array}$ & & & 0.767 \\
\hline Transactional Leadership-management by exception-active & 0.792 & 2.276 & \\
\hline $\begin{array}{l}\text { My leader focuses attention on irregularities, mistakes, } \\
\text { exceptions, and deviations from standards }\end{array}$ & & & 0.782 \\
\hline $\begin{array}{l}\text { My leader concentrates his/her full attention on dealing } \\
\text { with mistakes, complaints, and failures (excluded) }\end{array}$ & & & 0.241 \\
\hline My leader keeps track of all mistakes & & & 0.758 \\
\hline My leader directs my attention toward failures to meet standards & & & 0.762 \\
\hline Transactional Leadership-management by exception-passive & 0.792 & 2.357 & \\
\hline My leader fails to interfere until problems become serious & & & 0.734 \\
\hline $\begin{array}{l}\text { My leader waits for things to go wrong before taking } \\
\text { action (excluded) }\end{array}$ & & & 0.213 \\
\hline $\begin{array}{l}\text { My leader believes strongly that "If things are not broken, } \\
\text { do not fix it" }\end{array}$ & & & 0.704 \\
\hline $\begin{array}{l}\text { My leader demonstrates that problems must become } \\
\text { chronic before taking action. }\end{array}$ & & & 0.649 \\
\hline Transformational leadership - idealized influence & 0.851 & 4.372 & \\
\hline $\begin{array}{l}\text { My leader inculcates pride in me for being associated with } \\
\text { him/her }\end{array}$ & & & 0.823 \\
\hline My leader goes beyond self-interest for the good of the group & & & 0.751 \\
\hline My leader acts in a way that builds my respect & & & 0.794 \\
\hline My leader displays a sense of power and confidence & & & 0.758 \\
\hline $\begin{array}{l}\text { My leader talks about most important values and beliefs } \\
\text { (excluded) }\end{array}$ & & & 0.185 \\
\hline
\end{tabular}




\section{Leadership and organizational learning 23}

Table 3: to be continued...

\begin{tabular}{|c|c|c|c|}
\hline \multirow{2}{*}{ Item Description } & \multirow{2}{*}{$\begin{array}{l}\text { Reliability } \\
\text { ( } \alpha \text { value) }\end{array}$} & \multicolumn{2}{|c|}{ CFA analysis } \\
\hline & & Eig. val. & Loading \\
\hline $\begin{array}{l}\text { My leader specifies the importance of having a strong } \\
\text { sense of purpose }\end{array}$ & & & 0.761 \\
\hline $\begin{array}{l}\text { My leader considers the moral and ethical consequences } \\
\text { of decisions }\end{array}$ & & & 0.779 \\
\hline $\begin{array}{l}\text { My leader put emphasis on s the importance of having a } \\
\text { collective sense of mission }\end{array}$ & & & 0.806 \\
\hline Transformational leadership - inspirational motivation & 0.805 & 0.783 & \\
\hline My leader talks optimistically about the future & & & 0.754 \\
\hline $\begin{array}{l}\text { My leader discusses enthusiastically about what is needed } \\
\text { to be accomplished }\end{array}$ & & & 0.819 \\
\hline My leader articulates a compelling vision of the future & & & 0.851 \\
\hline My leader expresses confidence that goals will be achieved & & & 0.789 \\
\hline Transformational leadership - intellectual stimulation & 0.827 & 2.476 & \\
\hline $\begin{array}{l}\text { My leader re-examines critical assumptions to assess } \\
\text { whether they are appropriate }\end{array}$ & & & 0.801 \\
\hline $\begin{array}{l}\text { My leader looks for different perspectives when solving } \\
\text { problems }\end{array}$ & & & 0.816 \\
\hline My leader helps me to look at problems from different angles & & & 0.734 \\
\hline $\begin{array}{l}\text { My leader suggests new ways of looking at how to } \\
\text { complete tasks }\end{array}$ & & & 0.859 \\
\hline Transformational Leadership-individualized consideration & 0.714 & 2.312 & \\
\hline My leader spends time on teaching and coaching & & & 0.864 \\
\hline $\begin{array}{l}\text { My leader treats me as an individual rather than just a } \\
\text { member of a group (excluded) }\end{array}$ & & & 0.231 \\
\hline $\begin{array}{l}\text { My leader considers me as having different needs, abilities, } \\
\text { and inspirations from others }\end{array}$ & & & 0.819 \\
\hline My leader helps me to develop my strengths & & & 0.827 \\
\hline Organizational learning & 0.748 & 5.461 & \\
\hline $\begin{array}{l}\text { The employees attend training courses, fairs, conferences } \\
\text { and seminars regularly }\end{array}$ & & & 0.617 \\
\hline There is a consolidated and resourceful R \&D policy & & & 0.802 \\
\hline $\begin{array}{l}\text { New ideas and approaches on work performance are } \\
\text { experimented continuously }\end{array}$ & & & 0.698 \\
\hline $\begin{array}{l}\text { The university has formal mechanisms to guarantee the sharing } \\
\text { of the best practices among the diverse fields of the activities }\end{array}$ & & & 0.743 \\
\hline $\begin{array}{l}\text { There are individuals within my university who take part } \\
\text { in several teams or divisions and who also act as links } \\
\text { between them }\end{array}$ & & & 0.750 \\
\hline $\begin{array}{l}\text { There are individuals responsible for collecting, assembling } \\
\text { and distributing employees' suggestions internally. }\end{array}$ & & & 0.709 \\
\hline $\begin{array}{l}\text { All the members of my universities share the same goal } \\
\text { towards which they feel committed. }\end{array}$ & & & 0.727 \\
\hline $\begin{array}{l}\text { Employees share knowledge and experience by talking to } \\
\text { each other (excluded) }\end{array}$ & & & 0.291 \\
\hline Teamwork is very common practice in my university & & & 0.543 \\
\hline $\begin{array}{l}\text { The university has directories or emails filed according to } \\
\text { the field they belong to, so as to find an expert on a }\end{array}$ & & & 0.594 \\
\hline
\end{tabular}


24 IIUC Studies, 14(2)

Table 3: to be continued...

\begin{tabular}{lrr}
\hline Item Description & $\begin{array}{c}\text { Reliability } \\
(\alpha \text { value })\end{array}$ & \multicolumn{2}{c}{ CFA analysis } \\
\cline { 2 - 3 } & Eig. val. & Loading \\
Concrete issue at any time & 0.705 \\
The university has up to date databases and documents & \\
through some kind of network & 0.537 \\
$\begin{array}{l}\text { There is easy access to the university's databases } \\
\text { documents through some kind of network }\end{array}$ & \\
Databases are always kept up-to-date & 0.658 \\
\hline
\end{tabular}

The study explored a three-factor solution accounted for a $71.53 \%$ of total variance. The results of factor analysis revealed that some items got low factor loading as shown in Table 3. It is seen from the factor analysis that the first item, namely "My leader provides me assistance in exchange for my effort" of transactional leadership-contingent reward; the first item, namely "My leader focuses attention on irregularities, mistakes, exceptions, and deviations from standards" of transactional leadership-management by exception-active; the first item, namely "My leader fails to interfere until problem become serious" of transactional leadership-management by exception-passive; the item namely "My leader displays a sense of power and confidence" of transformational leadership-idealized influence; and the item namely-"My leader spends time for teaching and coaching" of transformational leadership-individualized consideration, have been excluded. The same items were also excluded in the study of Ayoubi (2015). Table 3 presents the factor loadings for the 32item scale. The significant loadings of all items for a particular factor indicated uni-dimensionality. It is to mention here that the results found no item with cross-loadings was identified and indicating the strength and construct validity. Besides, the reliability coefficients for all the three factors were greater than 0.70 , demonstrating adequate reliability (Nunnally, 1982).

\subsection{Regression analysis}

In order to answer the research question one, that examined the influence of transactional and transformational leadership styles on OL, the study applied multiple regression for both the leadership traits. Table 4 presents the output of regression analysis that investigated the relationship between transactional leadership and organizational learning and Table 5 demonstrates results of regression analysis showing the influence of transformational leadership on organizational learning. 


\section{Leadership and organizational learning 25}

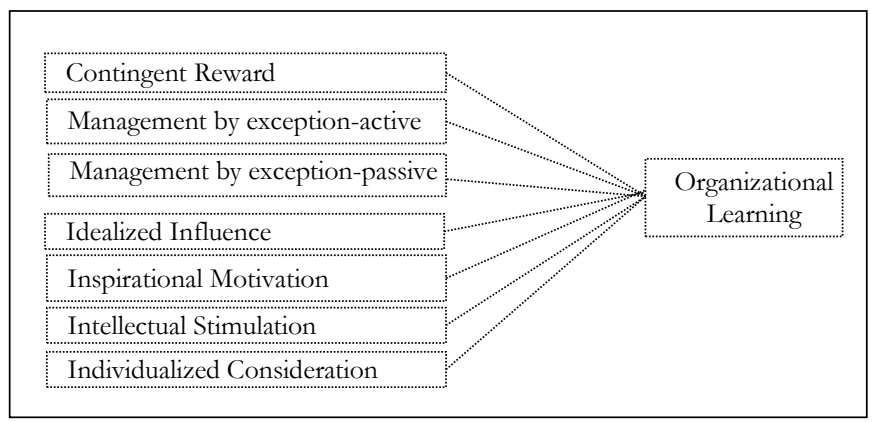

Figure 1: Source: Ayoubi (2015)

The regression model for the transactional leadership segment is stated as: Organizational learning $=\beta 0+\beta 1$ contingent reward $+\beta 2$ management by exception-active $+\beta 3$ management by exception-passive.

Table 4: Relationship between transactional leadership and organizational learning

\begin{tabular}{llcr}
\hline Leadership style & Dimension & Probability & $\beta$ \\
\hline \multirow{3}{*}{ Transactional leadership } & Contingent reward & $0.04^{*}$ & 0.36 \\
& Management by exception-active & 0.48 & 0.07 \\
& Management by exception-passive & 0.74 & -0.02 \\
\hline
\end{tabular}

Note: *Significant at 0.05

In terms of transactional leadership, as presented in Table 4, the results reported a significant influence of contingent reward on OL $(P$ value $=0.04<0.05$ ), having $\beta$ value of 0.36 . But the study did not explore any significant relationship between management by exception-active and passive and organizational OL $(p$-value $=0.48$ and $0.74>0.05$ successively).

Table 5: Relationship between transformational leadership and organizational learning

\begin{tabular}{llrr}
\hline Leadership style & Dimensions & Probability & $\beta$ \\
\hline Transformational leadership & Idealized influence & $0.02^{*}$ & 0.30 \\
& Inspirational motivation & 0.81 & 0.00 \\
& Intellectual stimulation & 0.51 & 0.06 \\
& Individualized consideration & $0.01 *$ & 0.32 \\
\hline
\end{tabular}

Note: *Significant at 0.05

The regression model for transformational leadership segment is stated as: $\mathrm{OL}=\beta 0+\beta 1$ idealized influence $+\beta 2$ inspirational motivation $+\beta 3$ intellectual stimulation $+\beta 4$ individualized consideration. 
In case of transformational leadership, the results revealed that idealized influence and individualized consideration have significant impact on organizational learning OL ( $p$-value $=0.02$ and $0.01<0.05$, successively). The beta $(\beta)$ value for idealized influence is 0.30 and for individualized consideration is 0.32 . This result indicates that organizational learning is significantly dependent on leadership practices demonstrated by the leaders in private universities in Bangladesh.

Table 6: Model summary

\begin{tabular}{lccccr}
\hline Model & R & R Square & $\begin{array}{l}\text { Adjusted } \\
\text { R Square }\end{array}$ & $\begin{array}{l}\text { Std. Error of } \\
\text { the Estimate }\end{array}$ & $\begin{array}{r}\text { Durbin- } \\
\text { Watson }\end{array}$ \\
1 & $.329 a$ & .196 & .181 & .69459 & 1.471 \\
\hline
\end{tabular}

Research question 2 that investigated the relative importance of the leadership dimensions in terms of their impact on OL. Results (Please see Table 4) indicate that contingent reward dimension of transactional leadership style was positively significantly related to organizational learning. Further, the regression results of the study reveals that contingent reward of the transactional leadership style (Table 4), and idealized influence and individualized consideration dimension (Table 5) are relatively significant aspects of leadership driving organizational learning. Finally, the overall model is accounted for 18 percent change in the dependent variable of organizational learning, as presented in Table 6. It indicates that transactional leadership and transformational leadership may bring 18 percent change in organizational learning among private university officials in Bangladesh.

\section{Discussion}

The results showed above indicate that contingent reward is significantly related to organizational learning. This result is in line with usual results reported in previous studies (Ayoubi, 2015; Bhat, Rangnekar, \& Barua, 2013; Coad \& Berry, 1998) that revealed a significant positive relationship between contingent rewards and OL. But the results did not report any significant influence of remedial measures, management by exceptionactive and passive on OL. Regarding transformational leadership, this study explored a significant effect of both idealized influence and individualized consideration on promoting organizational learning. However, findings of this research did not report any significant influence of inspirational motivation and intellectual stimulation on developing organizational learning. Similar findings were reported in previous studies investigating the relationship between transformational leadership and OL (Ayoubi, 2015; Coad \& Berry, 1998). This finding might be attributed to 
Leadership and organizational learning 27

the fact of politicization of recruitment, selection and promotion rather than based on performance and productivity. This politicization elevates the necessity for leadership behaviors in the context of Bangladesh. Although, contingent reward demonstrated a significant influence on facilitating organizational learning compared to inspirational motivation as well as intellectual stimulation. This finding could be attributed to the fact that the employees consider economic rewards and incentives more important than others (Patnaik, Beriha, Mahapatra, \& Singh, 2013). The findings also revealed that management by exception-active and passive did not find any significant impact on organizational learning which is consistent with a recent study conducted by Ayoubi (2015) on public and private universities in Syria. This might be because of the lack of use of the technique of management by exception. But the findings of the study of Ayoubi (2015), in terms of transactional leadership, are not consistent with this study. The results of this study reported that idealized influence and individualized consideration are significantly related with organizational learning whereas Ayoubi's (2015) study found only inspirational motivation having significant impact on learning. But the results of the study regarding transformational leadership are in tune with the results of the study conducted by Leithwood and Jantzi (2006).

\section{Contribution of the study}

The findings of this present research might have several implications. At first, though the influence of leadership styles on OL was studied by prominent researchers, it is still mainly at theoretical discussion (Ayoubi, 2015) and the majority of research works, in this regard, has been conducted in Western and developed economy context. Empirical research that investigated the impact of leadership practices on OL learning demonstrated incompatible results and hardly available in the perspective of emerging economies like Bangladesh. In view of this, this study could have significant contributions in the existing literature relating to measuring the impact of leadership in promoting learning process of organizations. Then studies on organizational learning are largely intended towards business and industrial enterprises rather than higher educational institutions. However, the number of research works conducted on higher educational institutions i.e. universities, are very little (Patnaik, Beriha, Mahapatra, \& Singh, 2013), that provides another marked contribution of this study.

\section{Limitations and future research}

In this research, data were collected from administrative staffs of three select private universities located in Chittagong. As this study did not 
include any faculty staff in the sample profile, this study recommends for future studies regarding leadership practices at including public universities in Bangladesh. First, future studies may include more private and public universities across the country. Most of private universities are located in Dhaka, the capital city of Bangladesh. This might help to produce stronger and more generalized results in this regard. Second, the future researchers should further investigate the impact of leadership practices on OL including academic staff that might be different from directing the administrative staff. Then, the future studies should focus on exploring underlying factors influencing the impact leadership styles on organizational learning, e.g. the institution may consider moderators like university cultures, university location, image of the university and structure. The future studies may also consider sample from other service sectors like banking, private health care, and hospitality sector.

\section{Conclusion}

The research examines the impact of leadership practices on promoting learning outcome of private universities in Bangladesh. Results of this study indicated positive relationships between transactional and transformational leadership between OL of the sample universities. Particularly, the contingent reward of transactional leadership style and idealized influence and individualized consideration of transformational leadership had significant influence in promoting learning of private universities. However, the study found no significant relationship between management by exception-active and passive of transactional leadership on the learning process of tertiary level private educational institutions in Bangladesh. This signifies that the leaders need to take remedial measures on the basis of leader-member interactions to make transactional leadership style more effective to accomplish the organizational goals. On the other hand, the leadership practices of inspirational motivation and intellectual stimulation regarding transformational leadership are not significantly related to organizational learning. This implies that the sample universities should provide the leadership to provide challenges and pursue the followers for better commitment and dedication as well as to motivate members to be creative, dynamic, and innovative in performing their duties and responsibilities. The findings also highlighted less importance of taking management by exception, inspirational motivation and intellectual stimulation into account as leadership behavior. Though, scholars suggested that management by exception, inspirational motivation, and intellectual motivation should be considered essential for higher 


\section{Leadership and organizational learning 29}

educational institutions like universities to achieve visionary goals (Ayoubi, 2015; Leithwood \& Jantzi, 2006; Spector \& Kim, 2014).

\section{References}

Albulushi, A., \& Hussain, S. (2008). Transformational leadership takes Majan to the top of the class: College wins string of prizes for good business practice. Human Resource Management International Digest, 16(2), 31-33.

Amitay, M., Popper, M., \& Lipshitz, R. (2005). Leadership styles and organizational learning in community clinics. The Learning Organization, 12(1), 57-70.

Andaleeb, S. S. (2003). Revitalizing higher education in Bangladesh: Insights from alumni and policy prescriptions. Higher Education Policy, 16(4), 487-504.

Aragon-Correa, J. A., Varcia-Morales, V. J., \& Cordon-Pozo, E. (2007). Leadership and organizational learning's role on innovation and performance: Lessons from Spain. Industrial Marketing Management, 36(3), 349-359.

Argyris, C. (1977). Double loop learning in organizations. Harvard Business Review, 55(5), 115-126.

Argyris, C., \& Schon, A. D. (1996). Organizational learning ii: Theory, method, and practice. Boston, MA: Addison-Wesley.

Avolio, B. J., Bass, B. M., \& Jung, D. I. (1999). Re-examination the components of transformational and transactional leadership questionnaire. Journal of Occupational and Organization Psychology, 72(4), 441-462.

Avolio, B.J., \& Bass, B.M. (2004). Multifactor leadership questionnaire: Manual and sampler set (3rd ed.). Redwood City, CA: Mind Garden Inc.

Ayoubi, B. K. R. M. (2015). Leadership styles at Syrian higher education. International Journal of Educational Management, 29(4). 477-491

Basham, L. M. (2010). Transformational and transactional leaders in higher education. International Review of Business Research Papers, 6(6), 141-152.

Bass, B. M. (1985). Leadership and performance beyond expectations. New York, NY: Free Press.

Bass, B. M. (1990). From transactional to transformational leadership: Learning to share the vision. Organizational Dynamics, 18(3), 19-31.

Bass, B. M. (1998). Transformational leadership: Industry, military, and education impact. New Jersey: Lawrence Erlbaum Associates.

Bass, B. M. (2010). Two decades of research and development in transformational leadership. European Journal of Work and Organizational Psychology, 8(1), 9-32.

Bass, B. M., \& Avolio, B. J. (1994). Improving organizational effectiveness through transformational leadership. Thousand Oaks, CA: Sage. 


\section{IIUC Studies, 14(2)}

Bhat, A. B., Rangnekar, S., \& Barua, M. (2013). Impact of transformational leadership style on organizational learning. Elite Research Journal of Education and Review, 1(4), 24-31.

Brown, L., \& Posner, B. (2001). Exploring the relationship between learning and leadership. Leadership and Organization Development Journal, 22(6), 274-280.

Bryant, S. E. (2016). The role of transformational and transactional leadership in creating, sharing and exploiting organizational knowledge. Journal of Leadership \& Organizational Studies, 9(4), 32-44. DOI: $10.1177 / 107179190300900403$

Burns, J. (1978). Leadership. New York, NY: Harper \& Row.

Cameron, K. S. (1981). Domains of organizational effectiveness in colleges and universities. Academy of Management Journal, 24(1), 25-47.

Castiglione, J. (2006). Organizational learning and transformational leadership in the library environment. Library Management, 27(4/5), 289-299. DOI: 10.1108/01435120610668223

Chang, S., \& Lee, M. (2007). A study on relationship among leadership, organizational culture, the operation of learning organization and employees' job satisfaction. The Learning Organization, 14(2), 155-185.

Coad, A., \& Berry, A. (1998). Transformational leadership and learning orientation. Leadership and Organization Development Journal, 19(3), 164-172.

Creswell, J. W. (2012). Educational research: Planning, conducting, and evaluating quantitative and qualitative research. Boston, MA: Pearson Education Inc.

Crossan, M., Lane, H., \& White, R. (1999). An organizational learning framework: from intuition to institution. Academy of Management Review, 24(3), 522-537.

Davenport, T. H., \& Prusak, L. (1998). Working Knowledge. Cambridge, MA: Harvard Business School Press.

Denton, J. (1998). Organizational Learning and Effectiveness. London: Routledge.

Drucker, P. F. (1993). Post-capitalist society. Oxford: Butterworth-Heinemann.

Easterby-Smith, M., Crossan, M., \& Nicolini, D. (2000). Organizational learning: Debates past, present, and future. Journal of Management Studies, 37(6), 784-796.

Edmondson, A. C. (1999). Psychological safety and learning behavior in work teams. Administrative Science Quarterly, 44(2), 350-383.

Fiol, C. M., \& Lyles, M. A. (1985). Organizational learning. Academy of Management Review, 10(4), 803-813.

Frank, A. G., \& Ribeiro, J. L. D. (2014). An integrative model for knowledge transfer between new product development project teams. Knowledge Management Research \& Practice, 12(2), 215-225.

Garvin, D. (1993). Building a learning organization. Harvard Business Review, 7(4), 78-91.

Hair, J., Black, W., Babin, B., Anderson, R., \& Tatham, R. (2010). Multivariate data analysis (7th ed.). Upper Saddle River, NJ: Pearson Education. 


\section{Leadership and organizational learning 31}

Hallinger, P. (2011). Leadership for learning: Lessons from 40 years of empirical research. Journal of Educational Administration, 49(2), 125-142.

Harms, P. D., \& Crede, M. (2010). Emotional intelligence and transformational and transactional leadership: A meta-analysis. Journal of Leadership \& Organizational Studies, 17(1), 5-17.

Howell, J. M., \& Avolio, B. J. (1993). Transformational leadership, transactional leadership, locus of control, and support for innovation: Key predictors of consolidated business-unit performance. Journal of Applied Psychology, 78(6), 891-902.

Huber, G. P. (1991). Organizational learning: The contributing processes and literatures. Organizational Science, 2(1), 88-115.

Jabbour, C. J. C., Jabbour, A. B. L., Teixeira, A. A., \& Freitas, W. R. S. (2012). Environmental development in Brazilian companies: The role of human resource management. Environmental Development, 3, 137-147.

Jansen, J. J. P., Vera, D., \& Crossan, M. (2009). Strategic leadership for exploration and exploitation: The moderating role of environmental dynamism. The Leadership Quarterly, 20(1), 5-18.

Kim, D. H. (1993). The link between individual and organizational learning. Sloan Management Review, 35(1), 37-50.

Krogh, G. V., Nonaka, I., \& Rechsteiner, L. (2012). Leadership in organizational knowledge creation: A review and framework. Journal of Management Studies, 49(1), 240-277.

Kurland, H., Peretz, H., \& Hertz-Lazarowitz, R. (2010). Leadership style and organizational learning: The mediate effect of school vision. Journal of Educational Administration, 48(1), 7-30.

Ladkin, D. (2012). Perception, reversibility, 'flesh': Merleau-Ponty's phenomenology and leadership as embodied practice. Integral Leadership Review, 12(1), 1-13.

Lam, T. L., \& Pang, S. K. (2003). The relative effects of environmental, internal and contextual factors on organizational learning: The case of Hong Kong schools under reforms. The Learning Organization, 10(2), 88-97.

Lam, Y. (2004). Factors for differential developments in organizational learning: a case for Hong Kong schools. International Journal of Educational Development, 24(2), 155-166.

Lamanga, C. Z. (2002). Strategic view of the development of higher education: Bangladesh AIUB perspective. Bangladesh Business Year Book, Dhaka: A1 Publication Ltd.

Lamanga, C. Z. (2006). Quality assurance in tertiary education: Bangladesh experience. In World Bank Learning Seminar (pp. 18-20).

Leithwood, K. (1992). The move toward transformational leadership. Educational Leadership, 49(5), 8-12. 


\section{IIUC Studies, 14(2)}

Leithwood, K., \& Jantzi, D., (2006). Transformational school leadership for largescale reform: Effects on students, teachers, and their classroom practices. School Effectiveness and School Improvement: An International Journal of Research, Policy and Practice, 17(2), 201-227. DOI: 10.1080/09243450600565829

Leithwood, K., Jantzi, D., \& Steinbach, R. (1999). Changing leadership for changing times. Buckingham: Open University Press.

Lipshitz, R., Popper, M., \& Friedman, V. J. (2002). A multi-facet model of organizational learning. Journal of Applied Behavioral Science, 38(1), 78-98.

Lopez, S. P., Peon, J. M. M., \& Ordas, C. J. V. (2004). Managing knowledge: The link between culture and organizational learning. Journal of Knowledge Management, 8(6), 93-104.

Moore, D. S., \& Notz, W. I. (2009). Statistics: Concepts and Controversies. New York, NY WH: Freeman and Company.

Morshed, M. (2016). Quality education in Bangladesh: Leadership roles of school heads and teachers to integrate technology in secondary school classrooms. Doctoral dissertation, Bowling Green State University.

Nafei, W. A., Khanfar, N. M., \& Kaifi, B. A. (2012). Leadership styles and organizational learning an empirical study on Saudi banks in Al-Taif Governorate Kingdom of Saudi Arabia. Journal of Management and Strategy, 3(1), 2-17.

Nakpodia, E. D. (2009). The concept of the university as learning organization: its functions, techniques and possible ways of making it effective. Journal of Public Administration and Policy Research, 1(5), 79-83.

Nunnally, J. C. (1982). Reliability of measurement. In H. E. Mitzel (Ed.), Encyclopedia of educational research (pp.1589-1601). New York: Free Press.

Oluremi, O. (2008). Principals' leadership behavior and school learning culture in Ekiti State secondary schools. The Journal of International Social Research, 1(3), 301-311.

Paille', P., Morin, D., \& Grima, F. (2011). Managing commitment to customer in the public sector: Highlight the role of the supervisor. International Journal of Services, Technology and Management, 16(3), 298-317.

Parvin, M. S. (2013). Integrations of ICT in education sector for the advancement of the developing country: Some challenges and recommendationsBangladesh perspective. International Journal of Computer Science \& Information Technology (IJCSIT), 5(4), 81-92.

Patnaik, B., Beriha, G. S., Mahapatra, S. S., \& Singh, N. (2013). Organizational learning in educational settings (technical): An Indian perspective. The Learning Organization, 20(2), 153-172.

Popper, M., \& Lipshitz, R. (2000). Installing mechanisms and instilling values: The role of leaders in organizational learning. The Learning Organization, 7(3), 135-145. 


\section{Leadership and organizational learning 33}

Pounder, J. S. (1999). Organizational effectiveness in higher education: Managerial implications of a Hong Kong study. Educational Management \& Administration, 27(4), 389-400.

Ramsden, P. (1998). Learning to lead in higher education. New York, NY: Routledge.

Reece, P. (2004). Universities as learning organizations: How can Australian universities become learning organizations? PhD thesis: Murdoch University, Perth, Western Australia.

Robbins, S. P., Bergman, R., Stagg, I., \& Coultar, M. (2003). Foundations of management. Sydney: Prentice Hall.

Rowley, J. (1998). Creating a learning organization in higher education. Industrial and Commercial Training, 30(1), 16-19.

Sabur, M. A. (2004). Dhaka University VS. Private University: A comparative analysis of quality of education offered by the institutions. An Unpublished BSS Thesis: University of Dhaka, Bangladesh.

Saekoo, A., \& Yasamorn, N. (2013). Strategic organizational learning and business growth: An empirical study of exporting gems and jewelry business in Thailand. Journal of the Academy of Business \& Economics, 13(2) 65-78.

Schein, E. H. (1993). How can organizations learn faster? The challenge of entering the greenroom. Sloan Management Review, 34(2), 85-92.

Sekaran, U. (2006). Research methods for business: A skill building approach. New Delhi: Wiley.

Sekaran, U., \& Bougie, R. (2010). Research methods for business-A skill building approach (5th ed.). London: John Willey \& Sons.

Senge, P. (1990). The fifth discipline: The art and practice of the learning organization. London: Century Business.

Shapnochary, R. (2015). Proposed education policy of Bangladesh. Badh Vangar Awaj. Retrieved

from

http://www.somewhereinblog.net/blog/rocky_dreammer/29093532

Silins, H., Zarins, S., \& Mulford, B. (2002). What characteristics and processes define a school as a learning organization? Is this a useful concept to apply to schools? International Education Journal, 3(1) 324-332.

Slater, S. F., \& Narver, J. C. (1995). Market orientation and the learning organization. Journal of Marketing, 59(3), 63-74.

Smart, J. C., Kuh, G. D., \& Tierney, W. G. (1997). The role of institutional cultures and decision approaches in promoting organizational effectiveness in two-year colleges. The Journal of Higher Education, 68(3), 256-281.

Spector, J. M., \& Kim, C. M. (2014). Technologies for intentional learning: Beyond a cognitive perspective. Australian Journal of Education, 58(1), 9-22.

Sun, P. Y. T., \& Anderson, M. H. (2011). The combined influence of top and middle management leadership styles on absorptive capacity. Management Learning, 43(1), 25-51. 


\section{IIUC Studies, 14(2)}

Teixeira, A. A., Jabbour, C. J. C., \& Jabbour, A. B. L. S. (2012). Relationship between green management and environmental training in companies located in Brazil: A theoretical framework and case studies. International Journal of Production Economics, 140(1), 318-329.

The Economist Intelligence Unit Limited. (2013). Higher education in the $21^{\text {st }}$ century: Meeting real-world demands. Available at: https://eiuperspectives.economist.com/sites/default/files/EIU AcademicP artns WEBr1.pdf

Theodore, J. (2013). Absence of transformational leadership in Greek enterprises results in the inability of forming learning organizations. International Business \& Economics Research Journal, 12(6), 701-706.

Tippins, M. J. \&, Sohi, R. S. (2003). IT competency and firm performance: Is organizational learning a missing link? Strategic Management Journal, 4(8), 745-761.

Trochim, W. M. (2006). The research methods knowledge base (2 $2^{\text {nd }}$ ed.). Internet WWW page, available at: http://www.socialresearchmethods.net/kb/

United Nations Development Programme. (UNDP) (2012). United Nations Development Programme project document: Country Bangladesh. Bangladesh: UNDP.

University Grants Commission (UGC). (2016). Annual Report of UGC. Dhaka: UGC.

University Grants Commission (UGC). (2017). Annual Report of UGC. Dhaka: UGC.

Vera, D., \& Crossan, M. (2004). Strategic leadership and organizational learning. Academy of Management Review, 29(2), 222-240.

Wagner, M. (2013). 'Green' human resource benefits: Do they matter as determinants of environmental management system implementation? Journal of Business Ethics, 114(3), 443-456. DOI: 10.1007/s10551-012-1356-9

Yukl, G. (1999). An evaluation of conceptual weakness in transformational and charismatic leadership theories. The Leadership Quarterly, 10(2), 285-305.

Zagoršek, H., Dimovski, V., \& Škerlavaj, M. (2009). Transactional and transformational leadership impacts on organizational learning. Journal of East European Management Studies, 14(2), 144-165.

Zhou, K. Z., Li, J. J., Zhou, N., \& Su, C. (2008). Market orientation, job satisfaction, product quality, and firm performance: Evidence from China. Strategic Management Journal, 29(9), 985-1000.

\section{Corresponding author}

Md. Mahi Uddin can be contacted at: mmur_cu@yahoo.com 